\title{
Natural evolution of alkaline characteristics in bauxite residue
}

by Kong, X., Guo, Y., Xue, S., Hartley, W., Wu, C., Ye, $\mathrm{Y}$. and Cheng, $\mathrm{Q}$.

Copyright, Publisher and Additional Information: This is the author accepted manuscript. The final published version (version of record) is available online via Elsevier Please refer to any applicable terms of use of the publisher.

DOI: https://dx.doi.org/10.1016/j.jclepro.2016.12.125

Harper Adams

University

Kong, X., Guo, Y., Xue, S., Hartley, W., Wu, C., Ye, Y. and Cheng, Q. 2016. Natural evolution of alkaline characteristics in bauxite residue. Journal of Cleaner Production.

23 December 2017 
2 Xiangfeng Kong a, b ${ }^{\text {, Yiwei, Li }}{ }^{\text {a, b }}$, Shengguo Xue ${ }^{\text {a, b, } * \text {, William Hartley }}{ }^{\text {c }}$, Xiaofei Li

a, b,

Jiaxin Liao ${ }^{\text {a, b }}$

${ }^{\text {a }}$ School of Metallurgy and Environment, Central South University, 932 Lushan South Road, Changsha, Hunan, 410083, PR China

${ }^{\mathrm{b}}$ Chinese National Engineering Research Center for Control \& Treatment of Heavy Metal Pollution, Central South University, Changsha, 410083, PR China

${ }^{\mathrm{c}}$ Crop and Environment Sciences Department, Harper Adams University, Newport, Shropshire, TF10 8NB, United Kingdom ${ }^{1}$

Abstract: Bauxite residue, a highly alkaline solid waste, is extremely hazardous to the surrounding environment and current research approaches have largely focused on the removal and separation of alkaline substances. Natural weathering processes may be a step forward in terms of their regeneration. In this study, natural evolution of basic alkalinity, electrical conductivity, exchangeable ions and acid neutralizing capacity of residue in the disposal areas is discussed. Minerals, exchangeable cations and alkaline anions were analyzed by X-ray powder diffraction (XRD), inductively coupled plasma atomic emission spectroscopy (ICP-AES) and titration, respectively. Acid neutralizing capacity was carried out by batch neutralization experiments. Basic alkalinity, electrical conductivity, cation exchange capacity and exchangeable sodium percentage decreased with increasing disposal duration. Sodium was the predominant exchangeable cation in fresh residue but its concentration significantly decreased with increasing time from initial disposal. The acid neutralizing capacity of bauxite residue was investigated by incubation with hydrochloric acid. Acid neutralizing capacity curves changed with disposal duration and each revealed a characteristic buffering behavior that could be controlled by its alkaline components.

*Corresponding author. Tel: +8673185552958

E-mail address: sgxue70@hotmail.com (S.G. Xue); sgxue@csu.edu.cn 
Keywords: Bauxite residue; Alkaline characteristics; Natural evolution; Exchangeable sodium; Acid neutralizing capacity; Environmental management

\section{Introduction}

As a result of the high demand for aluminum, the global alumina industry has developed rapidly. However, these rapid developments have triggered numerous environmental issues (Gelencser et al., 2011; Mayes et al., 2016; Ruyters et al., 2011) that severely restrict the sustainable development of the alumina industry. Bauxite residue (red mud) is an alkaline solid waste generated by extraction of alumina from bauxite in refineries. The volume of bauxite residue generated while producing one ton of alumina is typically about $0.5-2$ tons. With increasing demand for alumina worldwide, the global inventory of bauxite residue has reached an estimated 4 billion tons based on its current rate of production, and is still rapidly increasing (Kinnarinen et al., 2015; Liu and Naidu, 2014; Power et al., 2011). China is the largest producer of alumina in the world (Liu et al., 2014; Si et al., 2013). Its accumulative inventory of bauxite residue has reached over an estimated 0.6 billion tons with an annual increase of more than 70 million tons (Xue et al., 2016). Currently, almost all bauxite residue is stored indefinitely in land-based bauxite residue disposal areas (BRDAs) (Burke et al., 2013; Santini et al., 2015; Zhu et al., 2016a), which require continuous resources to manage and transform the waste and reduce its potential to contaminate water and land, as well as the surrounding ecology (Banning et al., 2014; Lockwood et al., 2015; Santini and Fey, 2015). Leaching of alkaline waste is a further potential problem (Buckley et al., 2016; Pulford et al., 2012; Samal et al., 2015). The adverse alkalinity means that bauxite residue is listed as a contaminated waste, which limits its disposal, applications and options for its sustainable reuse.

Many amelioration techniques have been developed in an attempt to reduce the alkalinity of bauxite residue. For example, seawater neutralization is used by some coastal refineries (e.g. Shandong Aluminium Industry Co., Ltd; Queensland Alumina), which involves the addition of excess seawater to convert soluble hydroxides, aluminates and carbonates into insoluble solids as calcite $\left(\mathrm{CaCO}_{3}\right)$, hydrocalumite 
$\left(\mathrm{Ca}_{4} \mathrm{Al}_{2}(\mathrm{OH})_{12} \cdot \mathrm{CO}_{3}\right)$, aluminohydrocalcite $\left(\mathrm{CaAl}_{2}\left(\mathrm{CO}_{3}\right)_{2}(\mathrm{OH})_{4} \cdot 3 \mathrm{H}_{2} \mathrm{O}\right)$, brucite $\left(\mathrm{Mg}_{3}(\mathrm{OH})_{6}\right)$ and hydrotalcite $\left(\mathrm{Mg}_{6} \mathrm{Al}_{2}\left(\mathrm{CO}_{3}\right)(\mathrm{OH})_{16} \cdot 4 \mathrm{H}_{2} \mathrm{O}\right)$ (Clark et al., 2015; Johnston et al., 2010; Menzies et al., 2004). Seawater neutralization lowers $\mathrm{pH}$ and alkalinity, but the generated colloidal particles are difficult to deal with. Carbon dioxide $\left(\mathrm{CO}_{2}\right)$ sequestration utilizes the reaction of $\mathrm{CO}_{2}$ with $\mathrm{OH}^{-}$to form $\mathrm{HCO}_{3}{ }^{-}$, and the reversibility of key alkalinity reactions between $\mathrm{OH}^{-}, \mathrm{CO}_{3}{ }^{2-}$ and $\mathrm{HCO}_{3}{ }^{-}$(Renforth et al., 2012; Wang et al., 2009; Yadav et al., 2010). The innovative nature of this technique is the consumption of $\mathrm{CO}_{2}$ to reduce atmospheric and industrial carbon dioxide emissions via sequestration (Cooling et al., 2002; Guilfoyle et al., 2005; Rai et al., 2013; Sahu et al., 2010). Interaction of waste acid can react with and transform hydroxides, oxides and sodalite (Freire et al., 2012; Lu et al., 2010), but the leached liquor and residue becomes a complex problem to manage, generating additional pollution issues (Burke et al., 2013; Goloran et al., 2015; Zhu et al., 2015a). Furthermore, the physical properties of bauxite residue present a problem, being a hostile environment for plant establishment (Borra et al., 2015; Kopittke, 2004; Zhu et al., 2015b). Gypsum transformation of bauxite residue lowers the $\mathrm{pH}$ by precipitating $\mathrm{OH}^{-}, \mathrm{Al}(\mathrm{OH})_{4}^{-}$, and $\mathrm{CO}_{3}{ }^{2-}$ as calcium hydroxide $\left(\mathrm{Ca}(\mathrm{OH})_{2}\right)$, tri-calcium aluminate $\left(\mathrm{TCA}, \mathrm{Ca}_{3} \mathrm{Al}_{2}(\mathrm{OH})_{12}\right)$, hydrocalumite $\left(\mathrm{Ca}_{4} \mathrm{Al}_{2}(\mathrm{OH})_{12} \cdot \mathrm{CO}_{3}\right)$ and calcite $\left(\mathrm{CaCO}_{3}\right)$ (Babu and Reddy, 2011; Courtney and Kirwan, 2012). The efficacy of gypsum in transforming the alkalinity is limited to gypsum's ability to readily dissolve (Courtney et al., 2009; Courtney and Harrington, 2012).

These amelioration strategies may temporarily contribute to reduce the alkalinity of bauxite residue, but nevertheless there remains insufficient long-term success due to side effects and economic issues. Many of the current research techniques have focused on artificial amelioration of alkaline substances with less attention being paid to the natural evolution of alkalinity and its occurrence in bauxite residue.

There is limited mechanistic understanding of bauxite residue alkalinity characteristics following its long term disposal. Indeed, lack of understanding of evolution chemistry and alkalinity behavior has been highlighted as a significant knowledge gap in relation to the safe management and revegetation of bauxite residue 
in BRDAs. This study therefore had the following specific objectives: (1) Discuss the changes in overall alkalinity of bauxite residue during its disposal history. (2) Identify the quantitative relationships between $\mathrm{EC}, \mathrm{Na}^{+}$and $\mathrm{OH}^{-}$. (3) Investigate the transformations in exchangeable cation and sodium percentages. (4) Understand the neutralization behavior following long term natural evolution of the residue.

\section{Materials and methods}

\subsection{Field sampling and sample handling}

The raw bauxite residue sample used in this study was collected at the BRDA of the Zhongzhou refinery, Aluminum Corporation of China, Henan province, China. Samples were collected from 5 locations as follows; freshly deposited residue (0 years)

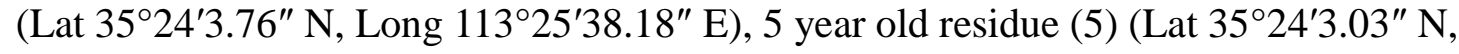
Long $113^{\circ} 25^{\prime} 38.82^{\prime \prime}$ E), 10 year old residue (10) (Lat 35²4'2.43" N, Long $113^{\circ} 25^{\prime} 38.26^{\prime \prime}$ E), 15 year old residue (15) (Lat 35²4'1.86" N, Long 11325'40.39" E)

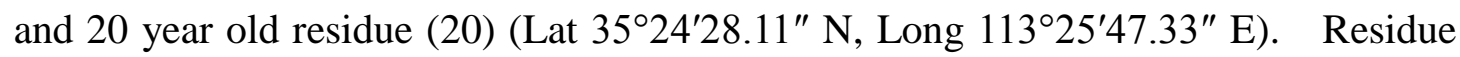
age differences are approximate but were determined due to a change in zonation which was clearly visible within the stacks. At each location, three sub-samples were collected with a distance of 5 meters from each other to form a representative sample. Samples were stored in polyethylene bags, returned to the laboratory and subsequently air-dried for 1 week, disaggregated using a mortar and pestle, and sieved to retain the $<2 \mathrm{~mm}$ fraction. Subsequently, X-ray powder diffraction (XRD) analysis was conducted on the samples using a Bruker D8 discover 2500 with a $\mathrm{Cu} K a_{1}$ tube using a Sol-X detector. X-ray diffraction patterns were collected from 10 to $80^{\circ}$ at a scan rate of $1^{\circ} 2 \theta / \mathrm{min}$ and a step size of $0.04^{\circ} 2 \theta$. XRD data analysis used the PANalytical analysis package to identify and quantify phases.

\subsection{Analytical methods}

Bauxite residue : water (1:5) extracts were prepared to determine $\mathrm{pH}$, electrical conductivity (EC), and alkaline anions, and a bauxite residue : 1mol/L ammonium acetate (1:5) extract was prepared to analyze exchangeable cations. Supernatant liquors 
114 from the water extraction were mixed at $150 \mathrm{rpm}(1 \mathrm{~h})$ then centrifuged at $3000 \mathrm{rpm}$

115 (10 min) and analyzed for pH and EC (Clark et al., 2015). Sodium, K, Ca and Mg in 116 ammonium acetate $(\mathrm{pH}=7)$ extracts were analyzed by inductively coupled plasma atomic emission spectroscopy (ICP-AES). Since no exchangeable acidic cations are expected to exist in alkaline conditions, the sum of exchangeable $\mathrm{Na}, \mathrm{K}, \mathrm{Ca}$ and $\mathrm{Mg}$ can be used as an estimate of cation exchange capacity (CEC).

Prepared supernatants from the water extraction were analyzed for alkaline anions (carbonate, bicarbonate and aluminate) by titration using a $0.02 \mathrm{~mol} / \mathrm{L} \mathrm{H}_{2} \mathrm{SO}_{4}$ standardized solution. The supernatant ( $5 \mathrm{~mL}$ ) was diluted with Milli-Q water to $30 \mathrm{ml}$. For solutions that were initially at a $\mathrm{pH}$ above 10.5 , the solution was titrated to $\mathrm{pH} 10.3$ (first titration), and then a $250 \mathrm{~g} / \mathrm{L}$ sodium gluconate solution was added until $\mathrm{pH}$ no longer increased. The solution was then titrated from $\mathrm{pH} 10.3$ (second titration) to $\mathrm{pH}$ 4.5 (third titration) (Kirwan et al., 2013). For solutions that were initially at a $\mathrm{pH}$ between 8.3 and 10.3, the solution was directly titrated to $\mathrm{pH} 4.5$ (third titration). From the first titration, the free hydroxide concentration $\left(\mathrm{OH}^{-}\right)$was determined. From the second titration, the aluminate concentration $\left(\mathrm{Al}\left(\mathrm{OH}_{4}\right)^{-}\right)$was determined, and from the third titration, the carbonate concentration $\left(\mathrm{CO}_{3}{ }^{2-}\right)$ was measured.

\subsection{Batch neutralization experiments}

Acid neutralizing capacity (ANC) from each of the 5 locations was determined by repeatedly titrating the supernatants. Samples $(10 \mathrm{~g})$ were weighed into conical flasks $(100 \mathrm{ml})$. Hydrochloric acid $(\mathrm{HCl})(0.5 \mathrm{~mol} / \mathrm{L})$ was subsequently added at $0.8 \mathrm{ml}$ increments, and made up to volume $(50 \mathrm{ml})$ with Milli-Q water. The supernatant liquors were then shaken by hand and $\mathrm{pH}$ determined immediately. Samples were then placed on a shaker operating at $120 \mathrm{rpm}\left(25^{\circ} \mathrm{C}\right)$. Supernatant $\mathrm{pH}$ was determined after $1 \mathrm{~min}$, then on day 1, 5, 15, 30 and 60 of shaking. Measurements were conducted on supernatants in the conical flasks without removal of any sample. All samples (each in duplicate) from the different disposal dates were used for ANC determinations. 


\section{Result and discussion}

142

143

144

145

146

147

148

154

\subsection{Transformation of basic alkalinity}

Basic alkalinity of the residue from the five locations are presented in Table 1. Following disposal, alkalinity decreased. For fresh residue, initial alkalinity was $28349.69 \mathrm{mg} / \mathrm{L} \mathrm{Na}_{2} \mathrm{CO}_{3}$, compared to $21857.02 \mathrm{mg} / \mathrm{L} \mathrm{Na}_{2} \mathrm{CO}_{3}$ from the 20 year old disposal area. Alkalinity is a result of the caustic solution from the Bayer process, and because of incomplete washing prior to disposal, alkaline substances (sodium hydroxide, $\mathrm{NaOH}$; sodium carbonate, $\mathrm{Na}_{2} \mathrm{CO}_{3}$; sodium aluminate, $\left.\mathrm{NaAl}(\mathrm{OH})_{4}\right)$ remain in the bauxite residue. During disposal, compounds such as $\mathrm{OH}^{-}, \mathrm{CO}_{3}{ }^{2-}$, and $\mathrm{Al}(\mathrm{OH})_{4}^{-}$, will undergo a chemical transformation. These reactions are expressed as Eqs. (1), (2) and (3). Notably, the concentration of $\mathrm{OH}^{-}$was greatly reduced after 15 years following disposal.

$$
\begin{aligned}
& \mathrm{OH}^{-}+\mathrm{H}^{+} \rightarrow \mathrm{H}_{2} \mathrm{O} \\
& \mathrm{CO}_{3}{ }^{2-}+\mathrm{H}^{+} \rightarrow \mathrm{HCO}_{3}{ }^{-} \\
& \mathrm{Al}(\mathrm{OH})_{4}{ }^{-}+\mathrm{H}^{+} \rightarrow \mathrm{Al}(\mathrm{OH})_{3}+\mathrm{H}_{2} \mathrm{O}
\end{aligned}
$$

Slaked lime $\left(\mathrm{Ca}(\mathrm{OH})_{2}\right)$ is commonly added within the Bayer process to improve digestion of alumina from the ore. This can lead to the formation of many solid phase calcium hydroxides, carbonates and aluminates, such as hydrogarnet $\left(\mathrm{Ca}_{3} \mathrm{Al}_{2}\left(\mathrm{SiO}_{4}\right)_{x}(\mathrm{OH})_{12-4 x}\right)$, calcite $\left(\mathrm{CaCO}_{3}\right)$ and tri-calcium aluminate (TCA, $\left.\mathrm{Ca}_{3} \mathrm{Al}_{2}(\mathrm{OH})_{12}\right)($ Fig. 1). These insoluble solids act as an alkali store and their dissolution (hydrogarnet, Eq. (4); calcite, Eq. (5); tri-calcium aluminate, Eq. (6)) can provide a continuous source of alkaline compounds $\mathrm{OH}^{-}, \mathrm{CO}_{3}{ }^{2-}$ and $\mathrm{Al}(\mathrm{OH})_{4}^{-}(\mathrm{Gomes}$ et al., 2015).

These alkaline anions are continuously consumed (Fig. 1), but even after 20 years, the alkalinity of the residue remained at a relatively high level; this may be attributed to these insoluble solid substances.

$$
\mathrm{Ca}_{3} \mathrm{Al}_{2}\left(\mathrm{SiO}_{4}\right)_{x}(\mathrm{OH})_{12-4 x} \rightarrow(6-4 \mathrm{x}) \mathrm{OH}^{-}
$$




$$
\begin{aligned}
& +3 \mathrm{Ca}^{2+}+2 \mathrm{Al}(\mathrm{OH})_{3}+x \mathrm{H}_{4} \mathrm{SiO}_{4} \\
& \mathrm{CaCO}_{3} \rightarrow \mathrm{Ca}^{2+}+\mathrm{CO}_{3}{ }^{2-} \\
& \mathrm{Ca}_{3} \mathrm{Al}_{2}(\mathrm{OH})_{12} \rightarrow 6 \mathrm{OH}^{-}+3 \mathrm{Ca}^{2+}+2 \mathrm{Al}(\mathrm{OH})_{3}
\end{aligned}
$$

166

The de-silication products (DSPs) are a sub-set of more general Bayer process characteristic solids (BPCSs) generated by the reaction of reactive silica with sodium hydroxide and which impart significant alkalinity to the residues. The main DSPs formed are Bayer sodalite $\left(\left[\mathrm{Na}_{6} \mathrm{Al}_{6} \mathrm{Si}_{6} \mathrm{O}_{24}\right] \cdot\left[2 \mathrm{NaOH}\right.\right.$ or $\left.\left.\mathrm{Na}_{2} \mathrm{CO}_{3}\right]\right)$ and cancrinite ([ $\left.\left.\mathrm{Na}_{6} \mathrm{Al}_{6} \mathrm{Si}_{6} \mathrm{O}_{24}\right] \cdot 2\left[\mathrm{CaCO}_{3}\right]\right)($ Fig. 1); they have a zeolite-type caged construction which can attach sodium. These anions tend to be dominated by $\mathrm{OH}^{-}, \mathrm{CO}_{3}{ }^{2-}$, and $\mathrm{Al}(\mathrm{OH})_{4}^{-}$. With natural disposal, it is difficult for these attached anions to be released and transformed. Hence in this way, DSPs can be a source of alkalinity. The natural transformation of these anions associated with the dissolution of DSP results in relatively stable alkalinity. However, with increasing duration following disposal, concentration of sodalite, hydrogarnet and calcite (Fig. 1) gradually reduced, whilst free hydroxides, carbonates and aluminates changed and the alkaline nature of the residue decreased.

\subsection{Transformation of electrical conductivity}

During disposal, EC decreased with increasing duration following disposal (Fig. 2). For fresh residue, the initial EC was $3.73 \mathrm{mS} / \mathrm{cm}$, compared to 0.36 in the 20 year old residue. During disposal, electrical conductivity affected the evolution of the residues alkaline characteristics. To elucidate the relationships between EC and alkaline sodium ions $\left(\mathrm{Na}^{+}\right)$and EC and hydroxide ions $\left(\mathrm{OH}^{-}\right)$linear curves were plotted (Fig. 3 and Fig. 4). High EC values present high concentrations of alkaline $\mathrm{Na}^{+}$and is replenished from Na-bearing solids. With increasing time from initial disposal, Na-bearing solids decreased with a corresponding decrease in EC (Fig. 2).

Electrical conductivity is also related to hydroxide ions $\left(\mathrm{OH}^{-}\right)$, and it is important to note that the linear relationship is approximately a factor of $1 / 3$. The linear curve was a good fit and showed EC $(\mathrm{mS} / \mathrm{cm}) \sim 1 / 3 \mathrm{OH}^{-}(\mathrm{mmol} / \mathrm{L})$ (Fig. 4). High EC values also 
demonstrate high concentrations of $\mathrm{OH}^{-}$. The dissolution reactions are the main source of $\mathrm{OH}^{-}$, which result in bauxite residue becoming weakly alkaline with increasing duration following disposal.

In the absence of detailed supernatant compositional data, EC is the most feasible quantity to estimate ionic strength. In natural aqueous solutions, Griffin and Jurinak (1973) determined the equation of EC 78 IS. The double-layer thickness of charged particles of bauxite residue becomes weak. Residue particles become dispersed, and the osmotic potential becomes more favorable. These transformed properties are beneficial to the disposal of bauxite residue and to stabilize the BRDA over the long term.

\subsection{Transformation of exchangeable cations}

The natural evolution of exchangeable cations ( $\mathrm{Na}, \mathrm{K}, \mathrm{Ca}, \mathrm{Mg}$ ) are presented in Fig. 5. Exchangeable $\mathrm{Na}$ decreased with increasing disposal time whilst exchangeable $\mathrm{K}$, $\mathrm{Ca}$ and $\mathrm{Mg}$ increased with increasing time following disposal. For fresh bauxite residue, the molar concentrations of various exchangeable cations were in the following decreasing order: $\mathrm{Na}>\mathrm{Ca}>\mathrm{Mg}>\mathrm{K}$. Exchangeable $\mathrm{Na}$ accounted for approximately $72 \%$ of the total exchangeable cations (mean molar concentration). This revealed that exchangeable $\mathrm{Na}$ dominated the basic cations in fresh bauxite residue. However, the concentration of exchangeable $\mathrm{Na}$ decreased from $20.28 \mathrm{cmol}_{\mathrm{c}} / \mathrm{kg}$ in fresh residue to $9.81 \mathrm{cmol}_{\mathrm{c}} / \mathrm{kg}$ in 20 year old residue. The concentration of exchangeable $\mathrm{Ca}$ increased from $6.96 \mathrm{cmol}_{\mathrm{c}} / \mathrm{kg}$ in fresh residue to $17.40 \mathrm{cmol}_{\mathrm{c}} / \mathrm{kg}$ in 20 year old residue. The increase in $\mathrm{K}$ and $\mathrm{Mg}$ was however not obvious, indicating that a large concentration of exchangeable $\mathrm{Na}$ was replaced with exchangeable Ca during the disposal process.

It should also be noted that the cation exchange capacity (CEC) of the residue decreased with increasing duration following disposal (Fig. 6). This may be attributed to a reduction in $\mathrm{pH}$ over time (Eq.(7), resulting in precipitation of $\mathrm{Ca}(\mathrm{OH})_{2}$ but also leaching of $\mathrm{NaOH}$. The original negatively charged $\left[\mathrm{Al}(\mathrm{OH})_{6}\right]^{3-}$ lost three $\mathrm{OH}^{-}$which resulted in zero-charged $\left[\mathrm{Al}(\mathrm{OH})_{3}\right]^{0}$ (Eq. (8)). Similar exchange reactions are available at edge sites of other alkaline compounds. The charged state of the colloids is therefore a significant regulator for cation exchange. During the time from disposal, with a 
reduction in CEC, the negatively charged sites became increasingly positive.

$$
\begin{aligned}
& {\left[\mathrm{Al}(\mathrm{OH})_{6}\right]^{3-}-} \\
& {\left[\mathrm{Na}^{+}+\mathrm{Ca}^{2+}\right]^{3+} \rightarrow\left[\mathrm{Al}(\mathrm{OH})_{3}\right]^{0}+\mathrm{NaOH}(\text { leaching })+\mathrm{Ca}(\mathrm{OH})_{2}(\text { precipitation })} \\
& {\left[\mathrm{Al}(\mathrm{OH})_{6}\right]^{3-}-3 \mathrm{OH}^{-} \rightarrow \text { zero-charged }\left[\mathrm{Al}(\mathrm{OH})_{3}\right]^{0}}
\end{aligned}
$$

The exchangeable sodium percentage (ESP) (Fig. 7) decreased with increasing duration following disposal. The ESP approximates to the composition of cation exchange sites on the residue surface as a result of the composition of exchangeable $\mathrm{Na}$, $\mathrm{Ca}$ and $\mathrm{Mg}$ (Gräfe and Klauber, 2011). Sodium ions can’t be dehydrated as readily as $\mathrm{Ca}$ and $\mathrm{Mg}$, which is indicative of stable hydration layers in bauxite residue particles. Additionally, Na ions can't be coordinated with negatively charged surfaces. The effect is that particles of fresh bauxite residue do not aggregate well and usually tend to be crusted and eroded in the dry state as Na eventually precipitates out as soda ash (trona and nahcolite), which simultaneously leads to the formation of alkaline dust and efflorescence at the surface of BRDAs (Klauber et al., 2008). The poor structural conditions at the surface of BRDAs are ultimately dependent on revegetation. With increasing time following disposal, the poor structural conditions may gradually be ameliorated (Zhu et al., 2016b).

\subsection{Transformation of Acid neutralizing capacity}

Acid neutralization of fresh residue shows changes in $\mathrm{pH}$ created by addition of hydrochloric acid (Fig. 8). Acid neutralizing capacity (ANC, final pH 7) of $1 \mathrm{~min}, 1,5$, 15, 30 and 60 days were $0.091 \mathrm{~mol} \mathrm{H}^{+} / \mathrm{kg}, 0.27 \mathrm{H}^{+} / \mathrm{kg}, 0.36 \mathrm{H}^{+} / \mathrm{kg}, 0.57 \mathrm{H}^{+} / \mathrm{kg}, 0.68$ $\mathrm{H}^{+} / \mathrm{kg}$ and $0.78 \mathrm{H}^{+} / \mathrm{kg}$ solids, respectively. Fig. 8 shows that the moles of $\mathrm{H}^{+}$taken to reach pH 7 increase as neutralizing time elapses, and most of the increase occurs at day 1 and 5. The curve at day 60 reveals an extensive horizontal section. Some of this neutralizing behavior can be attributed to soluble free $\mathrm{Na}_{2} \mathrm{CO}_{3}$ and $\mathrm{NaOH}$ (Eqs. (9) and (10)) occurring at the region of $\mathrm{pH}>8$. Much of this neutralizing behavior is associated with hydroxyls on the surfaces of iron oxides $\left(\mathrm{FeO}, \mathrm{Fe}_{2} \mathrm{O}_{3}-\mathrm{OH}\right.$, its reaction (Eq. (11) occurs at the region of $\mathrm{pH}<6$ ) in the bauxite residue and dissolution of sodalite, tricalcium aluminate and calcite $\left(\left[\mathrm{Na}_{6} \mathrm{Al}_{6} \mathrm{Si}_{6} \mathrm{O}_{24}\right] \cdot[2 \mathrm{NaOH}], \mathrm{Ca}_{3} \mathrm{Al}_{2}(\mathrm{OH})_{12}\right.$ and $\mathrm{CaCO}_{3}$ 
(Eqs. (12), (13) and (14) (Snars and Gilkes, 2009; Wissmeier et al., 2011; Xue et al., 2016). The length of the neutralizing region reflects the contents of these components in the bauxite residue.

$$
\begin{aligned}
& \mathrm{Na}_{2} \mathrm{CO}_{3}+\mathrm{H}^{+} \rightarrow 2 \mathrm{Na}^{+}+\mathrm{H}_{2} \mathrm{O}+\mathrm{CO}_{2} \\
& \mathrm{NaOH}+\mathrm{H}^{+} \rightarrow \mathrm{Na}^{+}+\mathrm{H}_{2} \mathrm{O} \\
& \mathrm{FeO}, \mathrm{Fe}_{2} \mathrm{O}_{3}-\mathrm{OH}+\mathrm{H}^{+} \rightarrow \mathrm{FeO}, \mathrm{Fe}_{2} \mathrm{O}_{3}+\mathrm{H}_{2} \mathrm{O} \\
& {\left[\mathrm{Na}_{6} \mathrm{Al}_{6} \mathrm{Si}_{6} \mathrm{O}_{24}\right] \cdot[2 \mathrm{NaOH}]+8 \mathrm{H}^{+}+10 \mathrm{H}_{2} \mathrm{O} \rightarrow 8 \mathrm{Na}^{+}+6 \mathrm{H}_{2} \mathrm{SiO}_{3}+6 \mathrm{Al}(} \\
& \mathrm{OH})_{3} \\
& \mathrm{Ca}_{3} \mathrm{Al}_{2}(\mathrm{OH})_{12}+6 \mathrm{H}^{+} \rightarrow 3 \mathrm{Ca}^{2+}+2 \mathrm{Al}(\mathrm{OH})_{3}+6 \mathrm{H}_{2} \mathrm{O} \\
& \mathrm{CaCO}_{3}+2 \mathrm{H}^{+} \rightarrow \mathrm{Ca}^{2+}+\mathrm{H}_{2} \mathrm{O}+\mathrm{CO}_{2}
\end{aligned}
$$
$\left[\mathrm{Na}_{6} \mathrm{Al}_{6} \mathrm{Si}_{6} \mathrm{O}_{24}\right] \cdot[2 \mathrm{NaOH}]+8 \mathrm{H}^{+}+10 \mathrm{H}_{2} \mathrm{O} \rightarrow 8 \mathrm{Na}^{+}+6 \mathrm{H}_{2} \mathrm{SiO}_{3}+6 \mathrm{Al}($
$\mathrm{OH})_{3}$
$\mathrm{Ca}_{3} \mathrm{Al}_{2}(\mathrm{OH})_{12}+6 \mathrm{H}^{+} \rightarrow 3 \mathrm{Ca}^{2+}+2 \mathrm{Al}(\mathrm{OH})_{3}+6 \mathrm{H}_{2} \mathrm{O}$$$
\text { The } \mathrm{pH}
$$$$
\text { region: > }
$$

The $\mathrm{pH}$

region

$<6$

The $\mathrm{pH}$

region:

6-8

The natural evolution of acid neutralizing capacity (ANC) (Fig. 9) was examined due to the characteristics of the fresh bauxite residue (Fig. 8). During disposal, ANC demonstrated some inconsistencies with increasing duration following disposal. For fresh residue, the initial ANC recorded (at $\mathrm{pH}$ 7) was $0.78 \mathrm{~mol} \mathrm{H}^{+} / \mathrm{kg}$ solid, which presents a strong ANC compared to $0.25 \mathrm{~mol} \mathrm{H}^{+} / \mathrm{kg}$ solid from the 20 year old residue. The ANC of fresh residue was higher than that of the residue disposed over the long term, which may be attributed to partial removal of $\mathrm{NaOH}$ and $\mathrm{Na}_{2} \mathrm{CO}_{3}$ by leaching during rainfall and alkali compound transformations. Furthermore, the curves for fresh and 5 year old residue (Fig. 9) present a broad horizontal section; the curves for 10, 15 and 20 year old residue (Fig. 9) only exhibit a narrow section. This neutralizing behavior is associated with the dissolution of sodalite, tricalcium aluminate, calcite and other alkaline compounds (Snars and Gilkes, 2009; Wissmeier et al., 2011). This tendency may demonstrate that fresh bauxite residue contains a larger concentration of sodalite, tricalcium aluminate and calcite, compared to aged residues (consistent with Fig. 1 results). Further, the acid neutralizing behavior may enhance the natural evolution 
of alkaline substances in bauxite reside following disposal.

\subsection{Environmental management for long-term disposal}

Historically, the management practices of BRDAs have focused on containment, with little attention given to long term changes in the chemical and physical properties of the residues. Currently, management plans are moving towards remediation and revegetation and/or further soil-formation of BRDAs to reduce environmental risks associated with long term disposal. Subsequently this will establish a stable ecosystem in the residue disposal areas, finally returning occupied land areas to an alternative option. In this work, alkalinity of bauxite residue was reduced with increasing duration following disposal. In addition, aged residue particles (10 to 20 years) had favorable osmotic potential that can't be considered dangerous to the surrounding environment and may be safely disposed. Furthermore, the long-term disposal of bauxite residue allows a significant decrease in exchangeable $\mathrm{Na}, \mathrm{EC}$, and $\mathrm{pH}$ values, which can increase the rate of revegetation. The ecological restoration of bauxite residue has many challenges due to its high alkalinity, salinity and sodium content, deficiencies in organic matter and nutrient concentrations. Recent research has indicated the possibility for surface revegetation by Bermuda grass (Cynodon dactylon) together with arbuscular mycorrhizal fungi (Babu and Reddy, 2011) and giant reed (Arundo donax L.) (Alshaal et al., 2013). Revegetation of bauxite residue following disposal in combination with phytoremediation may be a feasible option in the future.

Recently disposed bauxite residue presents potential threats to the environment such as leakage of alkaline compounds into groundwater, risk of caustic exposure to organisms, overflow of alkaline substances during storm events and the loss of alkaline dust and efflorescence forming at the surface of BRDAs, which require sustained and intensive resources to manage and transform their alkalinity. Several methods have been considered for safe disposal, including washing, dewatering, covering with vegetation, neutralization and wetland construction (Burke et al., 2013; Liu et al., 2014; Santini and Banning, 2016). It is critical that residues are washed and dewatered for separation of caustic liquors prior to disposal into BRDAs. Following this, the residue 
particles may aggregate well and be stable rather than crusted and become eroded. Furthermore, the formation of alkaline dust and efflorescence at the residue surface may be ameliorated and the residue may be safely stored for long-term natural regeneration.

297

\section{Conclusion}

This work provides evidence for the natural evolution of alkaline characteristics of bauxite residue in BRDAs following long term disposal. Bauxite residue has highly alkaline characteristics which decrease with increasing duration following disposal. High EC is related to $\mathrm{Na}^{+}$and $\mathrm{OH}^{-}$which appear to decrease with increasing disposal time. Cation exchange capacity and exchangeable sodium percentage decrease with increasing duration following disposal. Furthermore, Na was the predominant exchangeable cation in fresh residue but decreased over the long term being replaced with $\mathrm{Ca}$. Acid neutralizing capacity curves changed with disposal history and bauxite residue demonstrated a characteristic buffering behavior that further confirms the natural evolution of alkalinity. More importantly, these findings are applicable to surface revegetation and improved soil-formation because they demonstrate that decreasing alkalinity and increasing structural formation have a positive influence on the residues physical and chemical properties.

\section{Acknowledgements}

Financial supports from Environmental Protection's Special Scientific Research for Chinese Public Welfare Industry (No. 201509048), the National Natural Science Foundation of China (No. 41371475), the Open-End Fund for the Valuable and Precision Instruments of Central South University (No. CSUZC201610) and the Innovative Project of Independent Exploration for $\mathrm{PhD}$ of Central South University (No. 2016zzts036) are gratefully acknowledged. The writers also acknowledge the assistance of anonymous reviewers. 
Alshaal T., Domokos-Szabolcsy E., Marton L., Czako M., Katai J., Balogh P., Elhawat N., El-Ramady H., Fari M., 2013. Phytoremediation of bauxite-derived red mud by giant reed. Environ. Chem. Lett. 11, 295-302. http://dx.doi.org/10.1007/s10311-013-0406-6.

Babu A.G., Reddy M.S., 2011. Influence of arbuscular mycorrhizal fungi on the growth and nutrient status of bermudagrass grown in alkaline bauxite processing residue. Environ. Pollut. 159, 25-29. http://dx.doi.org/10.1016/j.envpol.2010.09.032.

Banning N.C., Sawada Y., Phillips I.R., Murphy D.V., 2014. Amendment of bauxite residue sand can alleviate constraints to plant establishment and nutrient cycling capacity in a water-limited environment. Ecol. Eng. 62, 179-187. http://dx.doi.org/10.1016/j.ecoleng.2013.10.034.

Borra C.R., Pontikes Y., Binnemans K., Van Gerven T., 2015. Leaching of rare earths from bauxite residue (red mud). Miner. Eng. 76, 20-27. http://dx.doi.org/10.1016/j.mineng.2015.01.005.

Buckley R., Curtin T., Courtney R., 2016. The potential for constructed wetlands to treat alkaline bauxite residue leachate: Laboratory investigations. Environ. Sci. Pollut. Res. 23, 14115-14122. http://dx.doi.org/10.1007/s11356-016-6582-8.

Burke I.T., Peacock C.L., Lockwood C.L., Stewart D.I., Mortimer R.J.G., Ward M.B., Renforth P., Gruiz K., Mayes W.M., 2013. Behavior of aluminum, arsenic, and vanadium during the neutralization of red mud leachate by $\mathrm{HCl}$, gypsum, or seawater. Environ. Sci. Technol. 12, 6527-6535. http://dx.doi.org/10.1021/es4010834.

Clark M.W., Johnston M., Reichelt-Brushett A.J., 2015. Comparison of several different neutralisations to a bauxite refinery residue: Potential effectiveness environmental ameliorants. Appl. Geochem. 56, 1-10. http://dx.doi.org/10.1016/j.apgeochem.2015.01.015.

Cooling D.J., Hay P.S., Guifoyle L., 2002. Carbonation of bauxite residue. Proceedings of the 6th International Alumina Quality Workshop, Brisbane.

Courtney R., Harrington T., 2012. Growth and nutrition of Holcus lanatus in bauxite residue amended with combinations of spent mushroom compost and gypsum. Land Degrad. Dev. 23, 144-149. http://dx.doi.org/10.1002/ldr.1062.

Courtney R., Kirwan L., 2012. Gypsum amendment of alkaline bauxite residue - Plant available aluminium and implications for grassland restoration. Ecol. Eng. 42, 279-282. http://dx.doi.org/ 10.1016/j.ecoleng.2012.02.025.

Courtney R.G., Jordan S.N., Harrington T., 2009. Physico-chemical changes in bauxite residue following application of spent mushroom compost and gypsum. Land Degrad. Dev. 20, 572-581. http://dx. doi.org/10.1002/ldr.926.

Freire T.S.S., Clark M.W., Comarmond M.J., Payne T.E., Reichelt-Brushett A.J., Thorogood G.J., 2012. Electroacoustic isoelectric point determinations of bauxite refinery residues: Different neutralization techniques and minor mineral effects. 

Langmuir. 28, 11802-11811. http://dx.doi.org/ 10.1021/la301790v.

Gelencser A., Kovats N., Turoczi B., Rostasi A., Hoffer A., Imre K., et al., 2011. The red mud accident in ajka (Hungary): Characterization and potential health effects of fugitive dust. Environ. Sci. Technol. 45, 1608-1615. http://dx.doi.org/10.1021/es104005r.

Goloran J.B., Phillips I.R., Condron L.M., Chen C., 2015. Shifts in leaf nitrogen to phosphorus ratio of Lolium rigidum grown in highly alkaline bauxite-processing residue sand with differing age of rehabilitation and amendments. Ecol. Indic. 57, 32-40. http://dx.doi.org/10.1016/j.ecolind.2015. 04.018.

Gomes H.I., Mayes W.M., Rogerson M., Stewart D.I., Burke I.T., 2015. Alkaline residues and the environment: A review of impacts, management practices and opportunities. J. Clean. Prod. http://dx.doi.org/10.1016/j.jclepro.2015.09.111.

Gräfe M., Klauber C., 2011. Bauxite residue issues: IV. Old obstacles and new pathways for in situ residue bioremediation. Hydrometallurgy. 108, 46-59. http://dx.doi.org/10.1016/j.hydromet.2011. 02.005.

Guilfoyle L., Hay P., Cooling D., 2005. Use of flue gas for carbonation of bauxite residue. Proceedings of the 7th International Alumina Guality Workshop, Perth, Australia.

Johnston M., Clark M.W., McMahon P., Ward N., 2010. Alkalinity conversion of bauxite refinery residues by neutralization. J. Hazard. Mater. 182, 710-715. http://dx.doi.org/10.1016/j.jhazmat. 2010.06.091.

Kinnarinen T., Lubieniecki B., Holliday L., Helsto J., Häkkinen A., 2015. Recovery of sodium from bauxite residue by pressure filtration and cake washing. Int. J. Miner. Process. 141, 20-26. http://dx.doi.org/10.1016/j.minpro.2015.06.006.

Kirwan L.J., Hartshorn A., McMonagle J.B., Fleming L., Funnell D., 2013. Chemistry of bauxite residue neutralisation and aspects to implementation. Int. J. Miner. Process. 119, 40-50. http://dx.doi.org/ 10.1016/j.minpro.2013.01.001.

Klauber C., Harwood N., Hockridge R., Middleton C., 2008. Proposed mechanism for the formation of dust horizons on bauxite residue disposal area. TMS Light Metals. 1, 19-24. http://dx.doi.org/ 10.1002/9781118647868.ch132.

Kopittke P.M., 2004. Limitations to plant root growth in highly saline and alkaline bauxite residue. J. Bio. Chem. 277, 44651-9.

Liu W., Chen X., Li W., Yu Y., Yan K., 2014. Environmental assessment, management and utilization of red mud in China. J. Clean. Prod. 84, 606-610. http://dx.doi.org/10.1016/j.jclepro.2014.06.080.

Liu Y., Naidu R., 2014. Hidden values in bauxite residue (red mud): Recovery of metals. Waste Manage. 34, 2662-2673. http://dx.doi.org/10.1016/j.wasman.2014.09.003.

Lockwood C.L., Stewart D.I., Mortimer R.J., Mayes W.M., Jarvis A.P., Gruiz K., Burke I.T., 2015. Leaching of copper and nickel in soil-water systems contaminated by bauxite residue (red mud) from Ajka, Hungary: The importance of soil organic matter. Environ. Sci. Pollut. Res. 22, 10800-10810. http://dx.doi.org/10.1007/s11356-015-4282-4.

Lu G., Chi S., Bi S., 2010. Leaching of alumina and iron oxide from red mud. J. Mater. Metal., 31-34, 67. (in Chinese) 
Mayes W.M., Burke I.T., Gomes H.I., Anton A.D., Molnar M., Feigl V., Ujaczki E., 2016. Advances in understanding environmental risks of red mud after the Ajka spill, Hungary. J. Sustain. Metal., 1-12. http://dx.doi.org/10.1007/s40831-0160050-z.

Menzies N.W., Fulton I.M., Morrell W.J., 2004. Seawater neutralization of alkaline bauxite residue and implications for revegetation. J. Environ. Qual. 33, 1877-1884. http://dx.doi.org/10.2134/jeq2004. 1877.

Power G., Gräfe M., Klauber C., 2011. Bauxite residue issues: I. Current management, disposal and storage practices. Hydrometallurgy. 108, 33-45. http://dx.doi.org/10.1016/j.hydromet.2011.02. 006.

Pulford I.D. et al., 2012. Carbonised red mud - a new water treatment product made from a waste material. J. Environ. Manage. 100, 59-64. http://dx.doi.org/10.1016/j.jenvman.2011.11.016.

Rai S.B., Wasewar K.L., Mishra R.S., Mahindran P., Chaddha M.J., Mukhopadhyay J., Yoo C., 2013. Sequestration of carbon dioxide in red mud. Desalin. Water Treat. 51, 2185-2192. http://dx.doi.org/ 10.1080/19443994.2012.734704.

Renforth P., Mayes W.M., Jarvis A.P., Burke I.T., Manning D.A.C., Gruiz K., 2012. Contaminant mobility and carbon sequestration downstream of the Ajka (Hungary) red mud spill: The effects of gypsum dosing. Sci. Total Environ. 421-422, 253259. http://dx.doi.org/10.1016/j.scitotenv. 2012.01.046.

Ruyters S., Mertens J., Vassilieva E., Dehandschutter B., Poffijn A., Smolders E., 2011. The red mud accident in ajka (Hungary): Plant toxicity and trace metal bioavailability in red mud contaminated soil. Environ. Sci. Technol. 45, 16161622. http://dx.doi.org/10.1021/es104000m.

Sahu R.C., Patel R.K., Ray B.C., 2010. Neutralization of red mud using $\mathrm{CO}_{2}$ sequestration cycle. J. Hazard. Mater. 179, 28-34. http://dx.doi.org/10.1016/j.jhazmat.2010.02.052.

Samal S., Ray A.K., Bandopadhyay A., 2015. Characterization and microstructure observation of sintered red mud-fly ash mixtures at various elevated temperature. J. Clean. Prod. 101, 368-376. http://dx.doi.org/10.1016/j.jclepro.2015.04.010.

Santini T.C., Banning N.C., 2016. Alkaline tailings as novel soil forming substrates: Reframing perspectives on mining and refining wastes. Hydrometallurgy. 164, 3847. http://dx.doi.org/ 10.1016/j.hydromet.2016.04.011.

Santini T.C., Fey M.V., 2015. Assessment of Technosol formation and in situ remediation in capped alkaline tailings. Catena. 136, 17-29. http://dx.doi.org/10.1016/j.catena.2015.08.006.

Santini T., Fey M., Gilkes R., 2015. Experimental simulation of long term weathering in alkaline bauxite residue tailings. Metals. 5, 1241-1261. http://dx.doi.org/10.3390/met5031241.

Si C., Ma Y., Lin C., 2013. Red mud as a carbon sink: Variability, affecting factors and environmental significance. J. Hazard. Mater. 244-245, 54-59. http://dx.doi.org/10.1016/j.jhazmat.2012.11.024.

Snars K., Gilkes R.J., 2009. Evaluation of bauxite residues (red muds) of different origins for environmental applications. Appl. Clay Sci. 46, 13-20. 
http://dx.doi.org/10.1016/j.clay.2009.06. 014.

Wang Q., Li J., Zhao Y., Luan Z., 2009. Study on the dealkalization of red mud by suspension and carbonation. Chin. J. Environ. Eng. 3, 2275-2280. (in Chinese)

Wissmeier L., Barry D.A., Phillips I.R., 2011. Predictive hydrogeochemical modelling of bauxite residue sand in field conditions. J. Hazard. Mater. 191, 306-324. http://dx.doi.org/10.1016/j.jhazmat. 2011.04.078.

Xue S.G., Kong X.F., Zhu F., Hartley W., Li X.F., Li Y.W., 2016. Proposal for management and alkalinity transformation of bauxite residue in China. Environ. Sci. Pollut. Res. 23, 1-13. http://dx. doi.org/10.1007/s11356-016-6478-7.

Xue S.G., Zhu F., Kong X.F., Wu C., Huang L., Huang N., Hartley W., 2016. A review of the characterization and revegetation of bauxite residues (Red mud). Environ. Sci. Pollut. Res. 23, 1120-1132. http://dx.doi.org/10.1007/s11356-015-4558-8.

Yadav V.S., Prasad M., Khan J., Amritphale S.S., Singh M., Raju C.B., 2010. Sequestration of carbon dioxide $\left(\mathrm{CO}_{2}\right)$ using red mud. J. Hazard. Mater. 176, 10441050. http://dx.doi.org/10.1016/ j.jhazmat.2009.11.146.

Zhu F., Xue S.G., Hartley W., Huang L., Wu C., Li X.F., 2016b. Novel predictors of soil genesis following natural weathering processes of bauxite residues. Environ. Sci. Pollut. Res. 23, 2856-2863. http://dx.doi.org/10.1007/s11356-015-5537-9.

Zhu F., Zhou J.Y., Xue S.G., Hartley W., Wu C., Guo Y., 2016a. Aging of bauxite residue in association of regeneration: A comparison of methods to determine aggregate stability \& erosion resistance. Ecol. Eng., 47-54. http://dx.doi.org/10.1016/j.ecoleng.2016.03.025.

Zhu X.B., Li W., Guan X.M., 2015a. Kinetics of titanium leaching with citric acid in sulfuric acid from red mud. T. Nonferr. Metal. Soc. 25, 3139-3145. http://dx.doi.org/10.1016/S1003-6326(15) 63944-9.

Zhu X.B., Li W., Guan X.M., 2015b. An active dealkalization of red mud with roasting and water leaching. J. Hazard. Mater. 286, 85-91. http://dx.doi.org/10.1016/j.jhazmat.2014.12.048. 